\title{
Allicin-induced modulation of angiogenesis in lung cancer cells (A549)
}

\author{
Layla Alhasan, Zuhair Radhi Addai \\ Biology Department, Education College for Pure Sciences, Thi-Qar University, Thi-Qar, Nasiriya 60041, Iraq \\ *For correspondence: Email: layla@eps.edu.iq, layla.alhassan14@gmail.com; Tel: +96-47816927081
}

\begin{abstract}
Purpose: To investigate the effectiveness of allicin as a candidate for lung cancer therapy. Methods: Allicin solution at different concentrations was tested on A549 lung cancer cell line. Viability and proliferation of A549 cells were determined. The cytotoxic effects of allicin solution on A549 lung cancer cells were quantitatively determined using Alamar blue assay. Cell proliferation and cell cycle were measured by DAPI-flow cytometry analysis in order to investigate the possible cell signalling pathway targeted by allicin. The level of expression of VEGF-A protein was determined with confocal laser scanning microscopy.

Results: Allicin inhibited lung cancer proliferation and down-regulated the protein expression of VEGF, but had no significant cytotoxic effects on A549 cells. Flow cytometric results showed that allicin induced cell cycle arrest of $A 549$ cells at the G1 phase.

Conclusion: These results indicate that allicin exerts anti-proliferative effects on A549 lung cancer cells. Thus allicin, an active component of garlic, might be a promising therapy against lung cancer metastasis.
\end{abstract}

Keywords: A549 cells, Allicin, qPCR Taqman assay, VEGF-A protein expression, Garlic, Lung cancer

\begin{abstract}
This is an Open Access article that uses a funding model which does not charge readers or their institutions for access and distributed under the terms of the Creative Commons Attribution License (http://creativecommons.org/licenses/by/4.0) and the Budapest Open Access Initiative (http://www.budapestopenaccessinitiative.org/read), which permit unrestricted use, distribution, and reproduction in any medium, provided the original work is properly credited.
\end{abstract}

Tropical Journal of Pharmaceutical Research is indexed by Science Citation Index (SciSearch), Scopus, International Pharmaceutical Abstract, Chemical Abstracts, Embase, Index Copernicus, EBSCO, African Index Medicus, JournalSeek, Journal Citation Reports/Science Edition, Directory of Open Access Journals (DOAJ), African Journal Online, Bioline International, Open-J-Gate and Pharmacy Abstracts

\section{INTRODUCTION}

The use of garlic (Allium sativum) in traditional medicine dates to back to $16^{\text {th }}$ century BC [1]. Research in recent decades demonstrate that garlic promotes well-being through reduction of blood level of bad cholesterol (LDL-cholesterol) which is linked to incidents of heart disease [2-5]. Studies have shown that allicin possesses antioxidant properties [5]. It is one of the most biologically active principles isolated from garlic, and its structure and properties were described by Gavallito and Bailey in $1944[6,7]$.
Several pharmacological properties have been ascribed to allicin: it possesses antioxidant, antiinflammatory, antibiotic, antiviral, and antiproliferative potential, and it enhances the viability of chondrocytes [8]. In addition, it has been reported that allicin inhibits cancer cells [1], and induces apoptosis via caspase-dependent and caspase-independent pathways through the enhancement of accumulation of reactive oxygen species [9]. Indeed, studies have demonstrated that allicin kills cancer cells and induces apoptosis in several cancer cell lines, as well as hepatocarcinoma, and lung cancer $[6,7]$. 
Combined use of allicin and cisplatin or carboplatin resulted in enhanced growth inhibitory effect on SW1736 and HTh?7 cells [10]. Furthermore, allicin has been reported to inhibit human renal clear cell carcinoma via suppression of the HIF pathway [11]. Moreover, allicin inhibited the proliferation of human mammary (MCF-7), endometrial (Ishikawa), and colon (HT-29) cancer cells [6]. Interesting, allicin can stimulate the immune system to produce some bioactive anticancer factors which inhibit tumour cells, and can also stimulate the release of many cytokines which enhance the immune system $[5,6,12]$.

Vascular endothelial growth factor (VEGF), first isolated from the pituitary gland [13] is a glycoprotein which is important in angiogenesis and vascular permeability, and it promotes endothelial proliferation and tumour growth. It is known that VEGF increases the permeability of blood vessels during tumour growth, thereby creating new blood vessels [14]. A study has reported that Melissa officinalis extract (MOE) significantly decreased the expression of VEGFA in A549 and MCF-7 cells [15]. The current research was designed to study the effect of allicin extract on lung cancer cells with a view to assessing its potential as an alternative therapeutic approach for inhibiting overexpression of VEGF-A.

\section{EXPERIMENTAL}

\section{Lung cancer cultivation}

Human alveolar basal epithelial adenocarcinoma cells (A549 cell line, ATCC\#CCL-185) were obtained from RMIT University, Australia. The cells were maintained at $37^{\circ} \mathrm{C}$ in complete DMEM medium (Life Technologies, Australia) containing $10 \%$ foetal bovine serum (FBS) and $1 \%$ penicillin/streptomycin $(10,000 \mathrm{U} / \mathrm{mL}$, Life Technologies, Australia) in a $5 \% \mathrm{CO}_{2}$ incubator.

\section{Assessment of cell viability}

The A459 cells were seeded at $2 \times 10^{4}$ cells $/ 100$ $\mu \mathrm{L}$ in 96-well plates overnight and treated with 5 , $12,25,50$ and $100 \mu \mathrm{g} / \mathrm{mL}$ of allicin (SigmaAldrich, Australia). Evaluation of cells was performed $24 \mathrm{~h}$ after treatment at $37{ }^{\circ} \mathrm{C}$ and in an atmosphere of $5 \% \quad \mathrm{CO}_{2}$. Cell viability was determined with AlamarBlueß assay [16].

\section{Proliferation assay}

The proliferation of the treated lung cancer cell lines (A549) was measured by quantifying their deoxyribonucleic acid (DNA) content using a Picogreen $\AA$ assay according to manufacturer's instructions. The cells were trypsinized after treatment at various allicin concentrations for 24 h. The cells were then rinsed two times with cold DPBS, followed by centrifugation for $5 \mathrm{~min}$ at $1200 \mathrm{rpm}$. The cell pellets were subsequently collected for lysis using a NP40 cell lysis buffer (Life Technologies, Australia) for $30 \mathrm{~min}$ on ice, and at 10-min intervals, the cell lysates were subjected to a freeze-thaw cycle prior to centrifugation at $13000 \mathrm{rpm}$ for $10 \mathrm{~min}$ at $4{ }^{\circ} \mathrm{C}$. A $100-\mu \mathrm{L}$ portion of clear lysate was aliquoted to a clean 96-well plate and incubated for $5 \mathrm{~min}$ with $100 \mu \mathrm{l}$ of PicoGreen® reagent at room temperature in the dark.

Fluorescence was measured using the multimode microplate reader at an excitation wavelength of $480 \mathrm{~nm}$ and an emission wavelength of $520 \mathrm{~nm}$. Cell numbers in the sample were determined by reference to a DNA standard curve. The DNA standard curve was obtained using cell lysates containing a known number of control cells.

\section{Cell cycle staining-DAPI}

After $24 \mathrm{~h}$ of treatment, treated and untreated cells were harvested using Trypel Express (Life Technologies), washed twice in PBS (to get rid of serum proteins) and centrifuged at $1200 \times \mathrm{g}$ for 5 min. The pellets $\left(3 \times 10^{6}\right.$ cells $)$ were resuspended in $1 \mathrm{~mL}$ PBS ( $\mathrm{Ca}$ - and $\mathrm{Mg}$-free). Ice-cold $95 \%$ ethanol ( $3 \mathrm{~mL}$ ) was added dropwise to the suspension, while vortexing. Then, the cells were fixed in $70 \%$ ethanol solution for $30 \mathrm{~min}$, and centrifuged at $2000-2200 \times \mathrm{g}$ for 10 min, washed again in $15 \mathrm{~mL}$ PBS; and recentrifuged at $2000-2200 \times \mathrm{g}$ for $10 \mathrm{~min}$. Thereafter, the cells were counted and resuspended in 0.5 - $2.0 \mathrm{~mL}$ DAPI stain solution, followed by 130 -min incubation on ice prior to flow cytometric analysis.

\section{Immunoassay}

Immunofluorescence was used to determine VEGA protein expression. Following fixation in paraformaldehyde, the treated and untreated cells were rinsed in phosphate buffered saline buffer (rinsing solution) containing Tween-20 (0.05 \%), prior to Triton X-100-mediated permeabilization. They were then blocked for $1 \mathrm{~h}$ with bovine serum albumin (1\%), rinsed trice in the rinsing solution, and incubated with antiVEGF-A primary antibody (diluted 1: 100) for $1 \mathrm{~h}$, followed by rinsing and incubation for $1 \mathrm{~h}$ with secondary antibody, then rinsing and staining with 4', 6-diamidino-2-phenylindole 
dihydrochloride. After rinsing, the cells were subjected to laser scanning confocal microscopy.

\section{TaqMan-qPCR assay}

In the determination of VEGF-A expression, RNA was extracted from treated and untreated cells using miniRNA kit (Qiagen, Australia) and subjected to reverse transcription to cDNA with QuantiTect (Qiagen, Australia). Then, qPCR was carried out under the following conditions: initial cycling at $95^{\circ} \mathrm{C}$ for $10 \mathrm{~min} ; 40$ cycles at $95^{\circ} \mathrm{C}$ for $15 \mathrm{sec}$, at $60{ }^{\circ} \mathrm{C}$ for $60 \mathrm{sec}$, and at $72{ }^{\circ} \mathrm{C}$ for 30 $\mathrm{sec}$, with GAPDH as internal control. The relative expression of VEGF-A was quantified using the ${ }^{2}-\triangle \Delta C T$ method [17].

\section{Statistical analysis}

Data are presented as mean \pm standard deviation (SD). One way analysis of variance (ANOVA) and Duncan's multiple range tests were used for statistical analyses of differences between the various groups, while two-group comparisons were done with Student's $t$-test. All statistical analyses were carried out with GraphPad Prism ver. 6.01. Values of $p<0.05$ were assumed significant.

\section{RESULTS}

To determine the effect of allicin on cell viability, the lung cancer cells (A549) were treated with 5 , $12,25,50$ and $100 \mu \mathrm{g} / \mathrm{ml}$ of allicin for $24 \mathrm{~h}$. Alamar blue assay demonstrated that allicin solution reduced lung cancer cell viability timeand dose-dependently. However, the effect of allicin on the lung cancer cells was not significant. These results are shown in Figure 1.

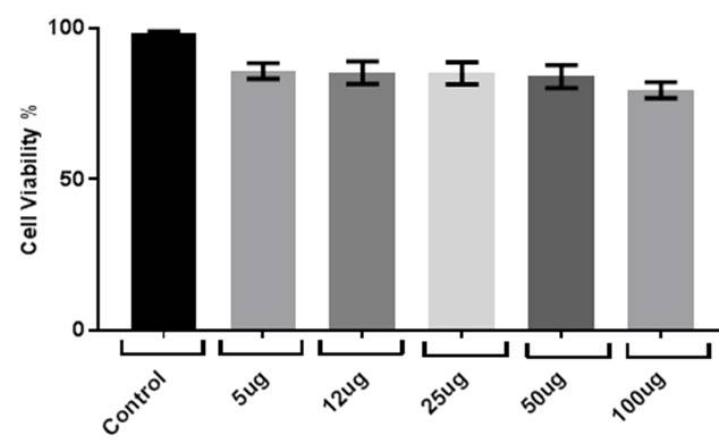

Figure 1: Effect of allicin on the viability of A549 cancer cell line. Cell toxicity was determined using AlamarBlue $\AA$ assay. Viability decreased with increased allicin concentrations, but was not statistically significant. Data were collected from multiple independent experiments and represented as mean \pm standard deviation
To evaluate the effect of allicin treatment on lung cancer cell proliferation, A549 cells were treated with different concentrations of allicin, and cell numbers were monitored for $24 \mathrm{~h}$. As shown in Figure 2, allicin significantly reduced the proliferation and growth of A549 cells. When compared with untreated controls, allicin reduced the proportion of cells in the $S$ phase cells and increased the proportion of cells in G2 phase due to cell arrest at the $\mathrm{G} 1$ phase (Figure 3).

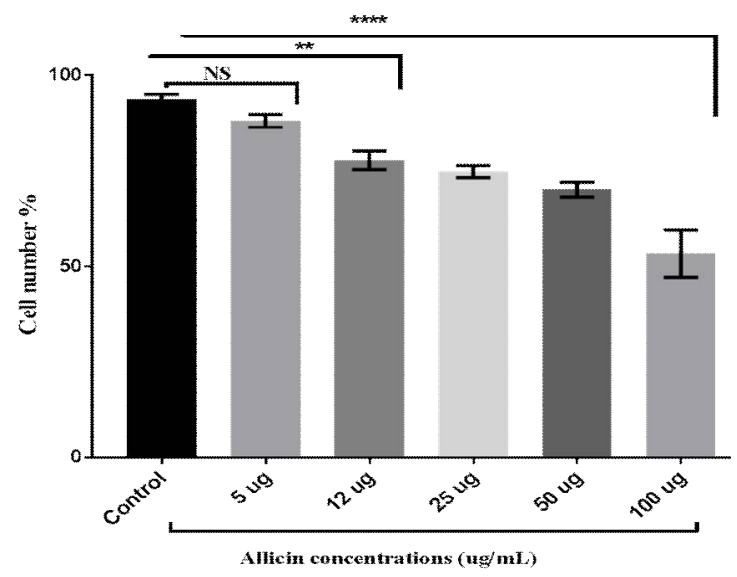

Figure 2: Effect of allicin on metabolic activity of lung cancer cells (A549), as measured using an PicoGreen $\AA$ assay. Data are presented as mean \pm SD

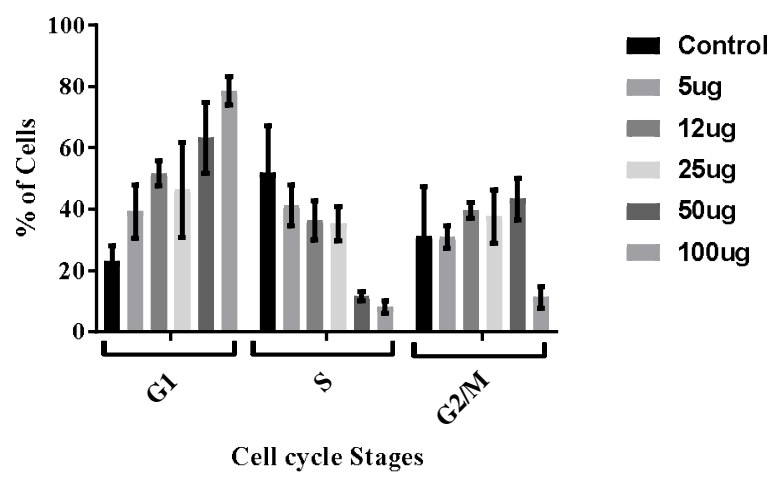

Figure 3: Effect of allicin on A549 cell cycle phases. Cells were arrested at G1 phase. Data from multiple independent experiments are presented as mean \pm SD

To study the impact of allicin on lung cancer cells which overexpress VEGF-A protein, the cells were exposed to different concentrations of allicin for $24 \mathrm{~h}$. Thereafter, they were examined microscopically and photographed to track the VEGF protein marker using immunoassay. The results confocal microscopy (Figure 4) revealed that after allicin treatment, VEGF-A (greenish colour) levels were reduced in A549 cells, when compared to control cells. This indicates that VEGF-A expression was significantly decreased, implying that allicin reversed the overexpression of VEGF-A overexpression induced effects. 
Thus, allicin exhibited a protective and anticancer property.

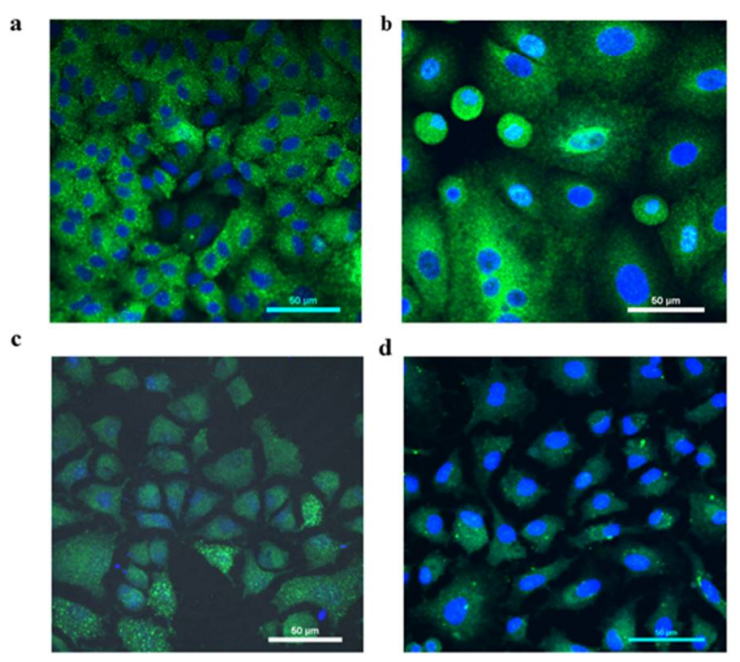

Figure 4: Immunofluorescence analysis of VEGF-A protein expression in untreated (a) and treated lung cancer cells. A549 cells were treated with $5 \mu \mathrm{g} / \mathrm{mL}$ (b), $50 \mu \mathrm{g} / \mathrm{mL}$ (c), $100 \mu \mathrm{g} / \mathrm{mL}$ (d) of allicin. Nucleated cells are in blue colour (DAPI). The protein level of VEGF-A was decreased, relative control cells. Scale bar represents $50 \mu \mathrm{m}$

Real-time PCR was done to confirm the effect of allicin on lung cell lines that over-express VEGFA. Cells were treated for $24 \mathrm{~h}$ with $100 \mu \mathrm{g} / \mathrm{ml}$, which was the concentration that yielded the highest inhibition of VEGF-A expression (as shown in confocal microscopy images). The VEGF-A gene was then measured using Taqman assay to track the vascular endothelial growth factor expression. The VEGF-A expression was significantly decreased (Figure 5), indicating that allicin can change the VEGF-A overexpression, thereby revealing the anticancer potential of allicin.

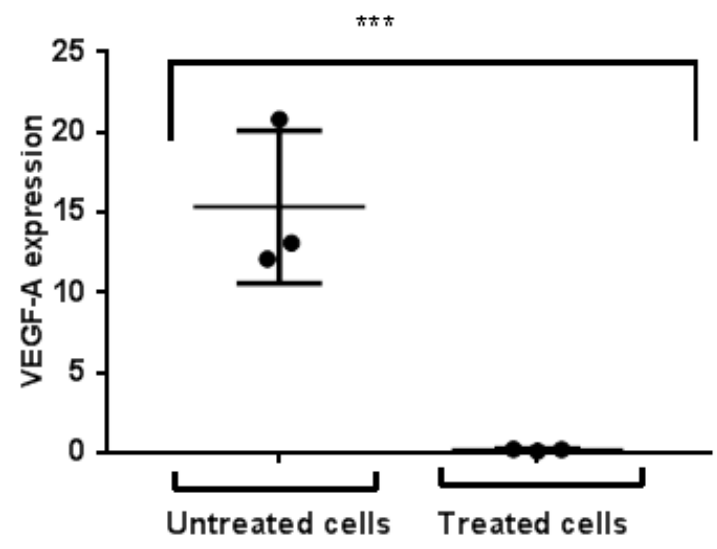

Figure 5: Reduction of VEGF-A expression in A549 cell line by allicin treatment. Cells were treated with $100 \mu \mathrm{g} / \mathrm{mL}$ allicin

\section{DISCUSSION}

Many studies on cancer cell lines have revealed that allicin has anticancer properties. It seems to be able to kill cancer cells and prevent their proliferation and growth. In the present study, exposure of lung cancer cells (A549) to allicin resulted in time- and dose-dependent decreases in viability as depicted in AlamarBlue $\AA$ assay. However, allicin did not produce any toxic effect on the lung cancer cells. These results are in agreement with previous findings [5, 9]. In contrast, some studies reported anti-tumour effect of allicin and its toxic effect on mammalian cell lines $[18,19]$.

In the present study, cell proliferation decreased with increasing concentrations of allicin, possibly due to increased stress on the cells at higher levels of allicin concentrations. The allicininduced reduction in proliferation also exerted a proportionate effect on metabolism in the A549 cells. This is in agreement with previous studies that demonstrated allicin-induced declines in the percentages of actively dividing MCF-7 and ZR75 cells [20]. In another study, it was reported that the percentage of cells in G0/G1 phase decreased with increase in the $S$ phase population of chondrocytes when lung cancer cells were exposed to allicin [8]. As shown in the present study, cells arrested at G1 phase were significantly high in all treated cells, relative to untreated cells. These correspond to high proportion of apoptotic cells. Some studies reported that allicin induced cell arrest of gastric cancer cells in M phase; this is could be correlated to the up-regulated expressions of p21WAF1 and p16INK4 genes [21].

In all treated cells, the protein expression of VEGF-A was low in A549 cells, when compared with control cells. This finding is consistent with a previous report which showed that allicin caused down-regulation of VEGF-A protein marker in lymph angiogenesis [22]. The results of the present study confirm that allicin indeed downregulates VEGF-A protein expression, suggesting that it acts as an anti-tumour drug. Real-time PCR results demonstrated that VEGF$A$ expression and overexpression were significantly decreased by allicin, which point to its anticancer property. These results are in agreement with previous findings [11,22]. The results obtained this study also show that VEGFA expression was significantly increased in control cells, even though allicin led to the reduction of VEGF-A in treated cells thereby inhibiting cell proliferation. Therefore, there was a strong correlation between the reduction in VEGF-A expression, and the results from laser 
scanning confocal microscopy and real time PCR.

\section{CONCLUSION}

The present study provides evidence that allicin possesses anti-proliferative effects when administered to lung cancer cell lines (A459), through down-regulation of vascular endothelial growth factor. Thus, allicin may be an effective treatment for lung cancer. Nevertheless, more investigations into other cell signalling pathways are required through in vivo testing of allicin to confirm it's as an effective treatment for lung cancer.

\section{DECLARATIONS}

\section{Acknowledgement}

Layla is grateful to Higher Education and Scientific Research/ Iraqi Government for the provision of a scholarship.

\section{Competing interests}

The authors declare that no competing interests exist with regard to this work.

\section{Contribution of Authors}

The authors declare that this work was done by the authors named in this article and all liabilities pertaining to claims relating to the content of this article will be borne by them.

\section{REFERENCES}

1. Block E. Garlic and Other Alliums. The Lore and The Science; RSC Publishing: Cambridge, UK. 2010.

2. Kleijnen J, Knipschild P, ter Riet G. Garlic, onions and cardiovascular risk factors. A review of the evidence from human experiments with emphasis on commercially available preparations. $\mathrm{Br} J \mathrm{Clin}$ Pharmacol 1989; 28(5): 535-544.

3. Ried K, Toben C, Fakler P. Effect of garlic on serum lipids: an updated meta-analysis. Nutr Rev 2013; 71 (5): 282-299.

4. Warshafsky S, Kamer RS, Sivak SL. Effect of garlic on total serum cholesterol. A meta-analysis. Ann Intern Med 1993; 119(7 Pt 1): 599-605.

5. Prasad K, Laxdal VA, YU M, Raney BL. Antioxidant activity of allicin, an active principle in garlic. Mol Cell Biochem 1995; 148: 183-189.

6. Hirsch K, Danilenko M, Giat J, Miron T, Rabinkov A, Wilchek M, Mirelman D, Levy J, Sharoni Y. Effect of purified allicin, the major ingredient of freshly crushed garlic, on cancer cell proliferation. Nutr Cancer 2000; 38(2): 245-254.

7. Chu YL HC, Chung JG, Rajasekaran $R$ and Sheen $L Y$. Allicin induces p53-mediated autophagy in Hep G2 human liver cancer cells. J Agric Food Chem 2012; 60: 8363-8371.

8. Li T, Shi HY, Hua YX, Gao C, Xia Q, Yang G, Li B. Effects of allicin on the proliferation and cell cycle of chondrocytes. Int J Clin Exp Pathol 2015; 12525-12532.

9. Belmokhtar CA, Hillion J, Ségal-Bendirdjian E. Staurosporine induces apoptosis through both caspasedependent and caspase-independent mechanisms. Oncogene 2001; 3354-3362.

10. Xiang $Y$, Zhao J, Zhao $M$, Wang $K$. Allicin activates autophagic cell death to alleviate the malignant development of thyroid cancer. Exp Ther Med 2018; 15(4): 3537-3543.

11. Song B, Shu Y, Cui T, Fu P. Allicin inhibits human renal clear cell carcinoma progression via suppressing HIF pathway. Int J Clin Exp Med 2015; 8(11): 20573-20580.

12. Park SY CS, Kwon HC, Lee KR, Rhee DK, Pyo S. Caspase-independent cell death by allicin in human epithelial carcinoma cells: involvement of PKA. Cancer Lett 2005; 224: 123-132.

13. Ferrara N, Henzel WJ. Pituitary follicular cells secrete a novel heparin-binding growth factor specific for vascular endothelial cells. Biochem Biophys Res Commun 1989; 161(2): 851-858.

14. Connolly DT, Olander JV, Heuvelman D, Nelson $R$, Monsell R, Siegel N, Haymore BL, Leimgruber R, Feder $J$. Human vascular permeability factor. Isolation from U937 cells. J Biol Chem 1989; 264(33): 20017-20024.

15. Esfahlana RJ, Seidia K, Monfaredan A, Irannejad VS, Abbasi MM, Karimian A, Yousefi B. The herbal medicine Melissa officinalis extract effects on gene expression of p53, Bcl-2, Her2, VEGF-A and hTERT in human lung, breast and prostate cancer cell lines. Gene 2017; 613: 14-19.

16. Alhasan L, Qi A, Rezk AR, Yeo LY, Chan PP. Assessment of the potential of a high frequency acoustomicrofluidic nebulisation platform for inhaled stem cell therapy. Integr Biol (Camb) 2016; 8(1): 12-20.

17. MW P. Relative quantification. Real-time PCR. Edited by: Dorak MT 2006, 63: 82 New York: Taylor and Francis Group. 2006.

18. Arditti FD, Rabinkov A, Miron $T$, Reisner $Y$, Berrebi A, Wilchek M, Mirelman D. Apoptotic killing of B-chronic lymphocytic leukemia tumor cells by allicin generated in situ using a rituximab-alliinase conjugate. Mol Cancer Ther 2005; 4: 325-332.

19. Miron T, Mironchik M, Mirelman D, Wilchek M, Rabinkov A. Inhibition of tumor growth by a novel approach: In situ allicin generation using targeted alliinase delivery. Mol Cancer Ther 2003; 1295-1301.

20. Vemuri SK, Banala RR, Subbaiah GPV, Srivastava SK, Reddy AVG, Malarvili T. Anti-cancer potential of a mix of natural extracts of turmeric, ginger and garlic: $A$ cellbased study. EJBAS 2017; 4(4): 332-344.

Trop J Pharm Res, November 2018; 17(11): 2133 
21. Ha MW, Yuan Y. Allicin induced cell cycle arrest in human gastric cancer cell lines. Zhonghua zhong liu za zhi. Chin J Oncol 2004; 26(10): 585-589.
22. Wang W, Du Z, Nimiya Y, Sukamtoh E, Kim D, Zhang G. Allicin inhibits lymphangiogenesis through suppressing activation of vascular endothelial growth factor (VEGF) receptor. J Nutr Biochem 2016; 29: 83-89. 